\title{
Molecular and genotypic study of SENV-D virus coinfection in $\beta$-thalassemic patients infected with the hepatitis $\mathrm{C}$ virus in Iraq
}

\author{
Sahar K. Al-Ani' ${ }^{1}$, Mushtak T.S. Al-Ouqaili², Muthanna M. Awad ${ }^{3}$ \\ ${ }^{1}$ Al-Anbar Health Office, Ramadi, Iraq, ${ }^{2}$ Department of Microbiology, University of Anbar, College of Medicine, \\ Ramadi, Iraq, ${ }^{3}$ Department of Biology, University of Anbar, College of Science, Ramadi, Iraq
}

Abstract

Objective and Background: SEN virus has identified as a putative new hepatitis virus coinfected with hepatitis C in thalassemic patients. The study aimed to measure viremia with SEN virus among thalassemic patients infected and non-infected with hepatitis $\mathrm{C}$ virus (HCV). Further, to detect the genotype D and the genetic alterations in the internal transcribed spacer domains/regions of SENV-D genotypes. Patients and Methods: A total of 200 $\beta$-thalassemic patients were included. HCV-RNA and SEN-DNA are extracting automatically. Then, amplification for SEN-DNA by conventional polymerase chain reaction (PCR) was achieved. Furthermore, HCV-RNA was amplified using real-time PCR (RT-PCR). Sequencing analysis was also done for 14 samples of amplified SENV-D DNA. Results: Out of 100 positive ELISA-anti-HCV antibodies which were definite for RT-PCR, the mean viral load in these patients was $545806 \pm 1,009,799 \mathrm{IU} / \mathrm{ml}(1,997,176 \pm 3,802,206)$ copies $/ \mathrm{ml}$. There was a significant increase in SENV-D in thalassemia patients without HCV infection (59\%) than those in thalassemia patients with $\mathrm{HCV}$ infection (44\%) and healthy subjects (7\%). In a sequencing study, 11 samples were infected with $\mathrm{D}$ genotype only while three from thalassemia patients group were coinfected with $\mathrm{D}$ and $\mathrm{H}$ genotypes. Conclusions: The occurrence rate of SEN-V DNA in thalassemia patients is very high in Iraq. Further, SEN-V-D genotype is more prevalent, and the sequences of SEN-V-D nucleotides in persons with coinfection are the same sequences of persons that have an infection with SEN-V-D alone. The most countries which have similar sequences to Iraqi SENV-D genotype sequence are Iran followed by China, Japan, Brazil, and the United States of America.

Key words: Coinfection, hepatitis $C$ virus, real-time polymerase chain reaction, $S E N,-\beta$-thalassemia

\section{INTRODUCTION}

I t is well documented that over $80 \%$ of hepatitis are caused by the most medically essential hepatitis viruses (From A to E), which usually known as hepatotropic viruses. ${ }^{[1]}$ The causative agent of the remaining $20 \%$ cases and also $10 \%$ transfusion-associated hepatitis is unknown, which may be interpreted to the involvement of other viruses. ${ }^{[2]} \beta$-thalassemia significant syndrome represents a group of inherited blood disorders caused by reduced or absent synthesis of the beta chains of hemoglobin of red blood cells. ${ }^{[3]}$ Due to the permanent use of blood products, the affected patients are more vulnerable to transmitted viruses by blood transfusion especially Hepatitis C virus (HCV). ${ }^{[4]}$ Blood transfusion in thalassemic patients increases their survival but carries the risk that they will acquire blood-borne virus infections, especially viral hepatitis. ${ }^{[5]}$ The latest virus suggested as a cause of this kind of hepatitis (non-A-E) is SEN virus. ${ }^{[6]}$
SEN virus (SENV) was first identified in the serum of a human immunodeficiency virus type 1-infected patient possessing hepatitis with unknown etiology in Italy on July 1999, injection drug user and name obtained on May 18,2000 , by the same scientist that discovered it. ${ }^{[7]}$ SENV is non-enveloped, round, icosahedral symmetry with a single-stranded DNA genome. ${ }^{[8]}$ The genome is circular, single-stranded of about 1.8-3.8 kb. SENV and Torque Teno Virus show a similar genomic organization; the nucleotide sequence had identified two dominant, partially overlapping open reading frames (ORFs), ORF1, and ORF2.. ${ }^{[9]}$ Nine

\section{Address for correspondence:}

Dr. Mushtak T.S. Al-Ouqaili, Department of

Microbiology, University of Anbar, College of Medicine,

Ramadi, Iraq. Mobile, +964 7830014212.

E-mail: ph.dr.mushtak_72@uoanbar.edu.iq

Received: $18-12-2018$

Revised: $27-12-2018$

Accepted: $31-12-2018$ 
distinct genotypes: SENV-A to- SENV-I had been identified, with SENV genotypes H (SENV-H) and D (SENV-D) being mostly associated with liver disease. ${ }^{[10]}$ Coinfection HCV is a primary cause of post-transfusion hepatitis and chronic liver disease. More than half of the patients with acute HCV infections develop chronic hepatitis that leads to cirrhosis, hepatocellular carcinoma (HCC), or both. ${ }^{[1]}$ Of patients with chronic HCV infection, 24-67\% are coinfected with SENV. ${ }^{[7]}$ The routes of SENV infection might be mostly parenteral, for example, transmission by blood transfusion, intravenous drug use, or hemodialysis. ${ }^{[12]}$ Transplantation of organs or hematological progenitor cells can also represent a potential risk of infection transmission. SENV has the same transmission modes as $\mathrm{HBV}$, and $\mathrm{HCV}^{[13]}$ sequences were used by several researchers to study the homology between isolated clones. ${ }^{[6,14]}$

The most common technique used for detection of SENV is polymerase chain reaction (PCR) through viral genome isolation and amplification using specific gene primers that react and catch the viral genome specifically. ${ }^{[15]}$ Thus, this study has been undertaken to measure viremia with SEN virus and cutoff diagnosis by PCR and detection the genotypes either by genotype $\mathrm{D}$ or $\mathrm{H}$ or both of them, further, to investigate the frequency and occurrence among thalassemic patients infected and non-infected with HCV detected by real-time PCR (RT-PCR) in Iraqi patients, and to recognize the genetic alterations in the internal transcribed spacer domains/regions of SENV-D and SENV-H genotypes through sequencing study of the homology of the study genomes and similarities of isolated clones between each isolate.

\section{SUBJECTS AND METHODS}

A total of $200 \beta$-thalassemia patients (96\% male and $104 \%$ female) were included in this study. They were referred to the Hereditary Blood Disease Center, Al-Karama Teaching Hospital/Baghdad. The age of study patients and healthy subjects was ranged from 3 to 44 years with mean $20 \pm 8.9$ who received regular blood transfusions, during the period from March to August 2017. All procedures performed in this study involving human participants were in accordance with the Ethical Approval Committee authentication no. 31 on December 6, 2017 - University of Anbar.

The study samples were divided into the following groups: Group I patients of thalassemia ( $\beta$-thalassemia patients received regular blood transfusion) that was composed of 100 patients (49\% male and 51\% female). All of them were infected with HCV. Group II consisted of patients of the thalassemia ( $\beta$-thalassemia patients received regular blood transfusion) that was composed of 100 patients (53\% male and $47 \%$ female) all of them were not infected with HCV. Group III consisted of healthy blood donors and randomly selected persons, this group composed of 100 people $(50 \%$ male, $50 \%$ female) were collected from Iraqi National
Center of Blood Transfusion and randomly chosen from the community. All exclusion criteria were applied to confirm their suitability for this group. They are healthy, afebrile, not jaundiced, no stigmata of chronic liver disease, and no contact with jaundiced patients.

\section{Serological Investigations}

\section{Biochemical investigations (liver enzymes)}

The Celercare ${ }^{\circledR}$ M1 Chemistry Analyzer, MINCHIP, China was used for detection of liver enzymes which includes alanine transaminase (ALT), aspartate aminotransferase (AST), alkaline phosphatase (ALP), total, serum bilirubin (TSB), and gamma-glutamyltransferase (GGT). Liver function panel lyophilized kit (MNCHIP) was used for detection of the above parameters automatically according to the manufacturer's instructions.

\section{Rapid immunochromatographic assay}

The detection of anti-HCV antibodies in the samples was performed by one step cassette, CTK, Biotech Company. The positive or negative results for anti-HCV antibodies in the study specimen were determined by the appearance of specific colored line on the cassette. ${ }^{[16]}$

\section{Detection of anti-HCV - antibody by ELISA}

All serum samples were tested for the presence of antibodies to $\mathrm{HCV}$ with a commercial ELISA kit (Human, Germany). Serum samples were added to these wells. If antibodies specific for $\mathrm{HCV}$ are present in the sample, they will form stable complexes with the HCV antigens on the well. A wash step extracted excess sample and a rabbit anti-human IgG conjugated with peroxidase is then added and allowed to incubate. The conjugate will bind to any formed complex of antigen-antibody. After a second wash, a solution of enzyme substrate and chromogen is added. This solution will develop a blue color if the sample is positive the blue color changes to yellow after blocking the reaction with sulfuric acid. The intensity of color measured by (ELISA reader, Awareness, USA) at $450 \mathrm{~nm}$ and it is proportional to anti-HCV antibodies concentration in the sample. Wells containing negative samples remain colorless. ${ }^{[16]}$

\section{Molecular Part of Study}

\section{Nucleic acids (HCV-RNA and SEN-DNA) extraction}

SaMag viral nucleic acids extraction kit which purchased from Sacace Biotechnologies, Italy was designed to be used with SaMag-12 automatic nucleic acid extraction system for the extraction of Viral DNA (SEV virus-DNA) and RNA (HCV-RNA) from human biological specimens (plasma).

The extraction process consisted of steps of lysis, binding, washing, and elution. The purification procedure was 
optimized for use with $150 \mu \mathrm{L}$ plasma. The frozen sample was thawed at room temperature $\left(15-25^{\circ} \mathrm{C}\right)$, and the samples were processed immediately when they have equilibrated to room temperature. The extraction was performed starting with the SaMag-12 instrument, as follow: Cartridges and reaction chambers were inserted. Furthermore, tip holders, piercing pins, small tip, and filtered tips were inserted. Sample tubes in the sample rack also entered, and $1.5 \mathrm{ml}$ elute tubes were embedded in the sample rack. Under a safe biological cabinet, samples were loaded in sample tubes. After that, the healthy internal subjects were added, and the sample rack was transferred into SaMag instrument. Then, SaMag-12 door was closed, and the barcode was used to select Viral Nucleic Acids Extraction kit protocol either SEN-DNA or HCV-RNA virus. ${ }^{[17-19]}$

\section{Determination of Concentration and Purity of DNA}

The extracted genomic DNA from blood samples was checked using Nanodrop Software (Bioneer, Korea). The measurement of the purity of DNA was achieved through reading the absorbance at $260 / 280 \mathrm{~nm}$ as the following steps: The nucleic acid application, DNA was opened and selected. Furthermore, an aliquot of $1 \mu 1$ of nuclease-free water was dispensed to lower optical surface lever arm. Then, closed and selected for application software that measured on 260/280 nm wavelength. After that, DNA concentration was measured in the sample. Nucleic acid concentration and purity ratios were automatically calculated by the software that was exhibited on the personal computer screen that is connected with Nanodrop. ${ }^{[20]}$

\section{HCV RT-PCR Quantification}

A kit for HCV Real-TM Quant is a real-time test for quantitative detection of $\mathrm{HCV}$ in human plasma. HCV RNA is extracted from plasma, amplified and detected using fluorescent reporter dye probes specific for HCV or HCV IC. Internal control (IC) serves as an extraction and amplification control for each individually processed specimen to identify possible inhibition. IC is detected in a particular and specific labeled channel other than the HCV RNA. Monitoring the fluorescence intensities during real-time allows the detection and quantification of the accumulating of the accumulating product without need open the reaction tube other time after the real-time amplification. ${ }^{[21]}$

\section{Reagent Preparation for Amplification}

One set of reagents was thawed, the tubes were vortexed and centrifuged briefly. Reaction tubes were prepared. Reaction Mix preparation was made as follow: $300 \mu 1$ of RT-PCRmix-1, $200 \mu \mathrm{l}$ of RT-PCR-mix-2, $20 \mu \mathrm{l}$ of host start Taq polymerase, and $10 \mu \mathrm{l}$ of M-MLV Reverse was added to the tube with DTT. The contents were vortexed thoroughly and centrifuged briefly. Then, for each sample (N) in the new sterile tube, $12.5 \mathrm{~N} \mu 1$ of the mix, $0.5 \mathrm{~N} \mu 1$ of Taq $\mathrm{F}$ polymerase, and $0.25 \mathrm{~N} \mu \mathrm{l}$ of M-MLV were added. $12.5 \mu \mathrm{l}$ of reaction mix added into each tube. Furthermore, $2.5 \mu \mathrm{l}$ of extracted RNA sample was added to the appropriate tube with reaction mix and mixed by pipetting, all the tubes with extracted RNA were re-centrifuged for $2 \mathrm{~min}$ at a maximum speed 16,000 g and supernatant was taken care. For each, run 6 standards and 1 negative control were prepared as follows: $12.5 \mu 1$ of quantitation standards $\mathrm{HCV}$ (QS1 HCV, QS2 HCV, and QS3 HCV) were added into 3 labeled tubes; $12.5 \mu \mathrm{l}$ of quantitation standards IC (QS1 IC, QS2 IC, and QS3 IC) were added in to 3 labeled tubes. After that, $12.5 \mu \mathrm{l}$ of TE-buffer was added to the tube labeled negative control, and the containers were transferred into the real-time instrument. The program for smart cycler was as follow Stage $1,50^{\circ} \mathrm{C}$ $1800 \mathrm{~s}$ (hold); stage $2,90^{\circ} \mathrm{C}-900 \mathrm{~s}$; stage 3 consisted of two temperature cycle $\left(95^{\circ} \mathrm{C}-20 \mathrm{~s}\right.$ and $\left.60^{\circ} \mathrm{C}-40 \mathrm{~s}\right)$. Step three was repeated for 42 times. The IC was detected on the FAM channel and HCV RNA on the CY3 channel. For each control and patient specimen, the concentration of HCV RNA was calculated using the following formula: HCV RNA copies/ specimen (the CY3 channel)/IC RNA copies/specimen (FAM channel) $\times$ coefficient $=\mathrm{IU} \mathrm{HCV} / \mathrm{ml}$. To obtain the results expressed in copies/ml multiply the IU $\mathrm{HCV} / \mathrm{ml}$ value by 4) as follow: IU RNA HCV $/ \mathrm{mL} \times 4=$ copies RNA HCV/ml. ${ }^{[19,20]}$

\section{Amplification for SEN-DNA by Conventional PCR}

Two primers (forward and reverse) are the request and provided by Alpha DNA Company, Canada in a lyophilized form. The primers used in the study were SENV-AI-IF: With sequences 5'TACTCCAACGACCAGCTAGACCT3'; SENVAI-IR with the sequences: -5'GTTTGTGGTGAGCAGAACG GA3'; SENV-D-1148 F: Sequence: 5'GCAGTTGACCGCAA AGTTACAAGAG3'; SENV-D-1341R: Sequence: 5'GCAGT TGACCGCAAAGTTACAAGAG3'. Template DNA and primers were added to the AccuPower PCR tube. Then, free nuclease water was added to AccuPower PCR tubes to a total volume of $50 \mu$ l. PCR reaction kit (premix) was selected from the Pioneer. The PCR reaction was carried out in $50 \mu \mathrm{l}$ solution containing premix Taq DNA polymerase, $250 \mu \mathrm{M}$ (each) dATP, dGTP, dCTP, dTTP and $1.5 \mathrm{Mm} \mathrm{MgCl} 2$, reaction buffer (PH 9), and loading dye buffer (yellow and blue dye), $2 \mu 1$ each of amplification primers, $10 \mu 1$ target DNA, and $36 \mu \mathrm{l}$ free nuclease water. Template DNA and primers were added to the AccuPower PCR tube. Then, free nuclease water was added to AccuPower PCR tubes to a total volume of $50 \mu 1$. Nested conventional PCR17 performed amplification of genomic DNA.

Nested conventional PCR had amplified DNA of SEN virus. First, the specific reaction contents have been add and the PCR protocol as follow: The PCR protocol used for the first round amplification was: $94^{\circ} \mathrm{C}$ for $4 \mathrm{~min}, 1$ cycle to initial denaturation the template; 35 cycles of $94^{\circ} \mathrm{C}$ for $40 \mathrm{~s}$ to denaturation, $55^{\circ} \mathrm{C}$ for $50 \mathrm{~s}, 35$ cycles for annealing, and $72^{\circ} \mathrm{C}$ 
for $50 \mathrm{~s}, 35$ cycles for extension; finally, $72^{\circ} \mathrm{C}$ for $10 \mathrm{~min}$ and 1 cycle for final extension. The second run of PCR protocol was as follow: $-94^{\circ} \mathrm{C}$ for $4 \mathrm{~min}, 1$ cycle for initial denaturation the template; 35 cycles of $94^{\circ} \mathrm{C}$ for $30 \mathrm{~s}$ for denaturation, $55^{\circ} \mathrm{C}$ for $50 \mathrm{~s}, 35$ cycles for annealing and $72^{\circ} \mathrm{C}$ for $50 \mathrm{~s}$, and 35 cycles for extension; finally, $72^{\circ} \mathrm{C}$ for $10 \mathrm{~min}$ and 1 cycle for final extension. After that, $10 \mu \mathrm{l}$ of amplified DNA was mixed with $4 \mu \mathrm{l}$ from red save than loaded on to the gel pocket with the presence of molecular weight marker. The electrophoresis was then carried out for about $1 \mathrm{~h}$ with the following conditions ( 5 volt $/ \mathrm{cm}, 100$ watts, and $60 \mathrm{~m}$ ). Gel electrophoresis system was turned on and adjusted at 100 volts for $1 \mathrm{~h}$. When the electrophoresis was completed, the gel was placed on a UV transilluminator (proper face protection against UV radiation was worn). A digital picture was made for evaluation and documentation. ${ }^{[21]}$

\section{Sequencing}

Sequencing of PCR product was carried out by NICEM Company (South Korea) by sending the PCR DNA products with their specific primers by freezer bag. The sequencing study as designed between the sequence of standard gene BLAST program which is available at National Center of Biotechnology Information (NCBI) online at http:// www.ncbi.nlm.nih.gov and using BioEdit program. The evolutionary analysis was conducted using MEGA6 (Molecular Evolutionary Genetics Analysis software version 6 software). ${ }^{[22]}$

\section{Statistical Analysis}

Analysis of data was accomplished using the available statistical package of SPSS-22 (Statistical Package for the Social Sciences - version 22). Data were presented in simple measures of frequency, percentage, mean, standard deviation, and range (minimum-maximum values). The significance of the difference of different means (quantitative data) was tested using Student's - $t$-test for the difference between two independent means or Paired - $t$-test for difference of paired observations (or two dependent means), or ANOVA test for difference among more than two independent means. The significance of the difference in different percentages (qualitative data) was tested using the Chi-square test ( $\sum$-test) with the application of Yate's correction or Fisher Exact test whenever applicable. Statistical significance was considered whenever $P$ value for the analysis of importance was $\leq 0.05{ }^{[23,24]}$

\section{RESULTS}

A total of 100 patients with a high suspicion of HCV infection revealed positive rapid immunochromatographic assay while the other 100 thalassemic patients and 100 healthy subjects were yielded negative results with a high statistical difference
$(P<0.0005)$. Regarding the ELISA test, it was found that the results of the rapid immune chromatography assay agreed with those of ELISA in 100 cases. All individuals of healthy subjects group revealed negative ELISA results for anti-HCV antibody in their sera.

Thalassemia group had been subdividing according to the SENV and HCV infections into four subgroups, HCV positive and SENV positive as subgroup I, SENV positive and HCV negative as subgroup II, SENV negative and HCV positive as subgroup III, and SENV and negative and HCV negative as subgroup IV. Healthy subjects also had been subdivided into two subgroups according to SENV infection because they had been chosen as HCV free to be healthy persons, SENV positive (subgroup V) and SENV negative (subgroup VI) as reflected by the following Figure 1 .

Regarding viral load, the quantity of virus, out of 100 positive ELISA - anti-HCV antibodies, $72(72 \%)$ were definite for RT-PCR considering the assay threshold for our procedure was $>13 \mathrm{IU} / \mathrm{ml}$. The mean viral load in these patients was $545,806 \pm 1,009,799 \mathrm{IU} / \mathrm{ml}(1,997,176 \pm$ $3,802,206$ copies/ml) as shown in Table 1.

A total of 200 thalassemia patients $(96 \%$ male and $104 \%$ female), with a mean age of $21.5 \pm 8.4$ years, and 100 healthy subjects with randomly selected persons considered as healthy subjects $(50.0 \%$ male and $50.0 \%$ female $)$, with a mean age of $18.8 \pm 9.6$ years. Statistical analysis shows a significant $(P>0.05)$ increase in SENV prevalence in thalassemia patients compared to healthy subjects as reflected in the following Table 2.

Nested conventional PCR had identified SENV infection, and the results revealed that there was a significant increase in the occurrence of SENV among thalassemia patients in comparison with healthy subjects as a result of blood transfusion as a source of virus infection. Nested conventional PCR had identified SENV, and the bands were detected by agarose gel electrophoresis to differentiate between 193 bp of SENV-D, 118 bp of SENV- H and both of them together in the same individual as a copresence [Figures 2 and 3].

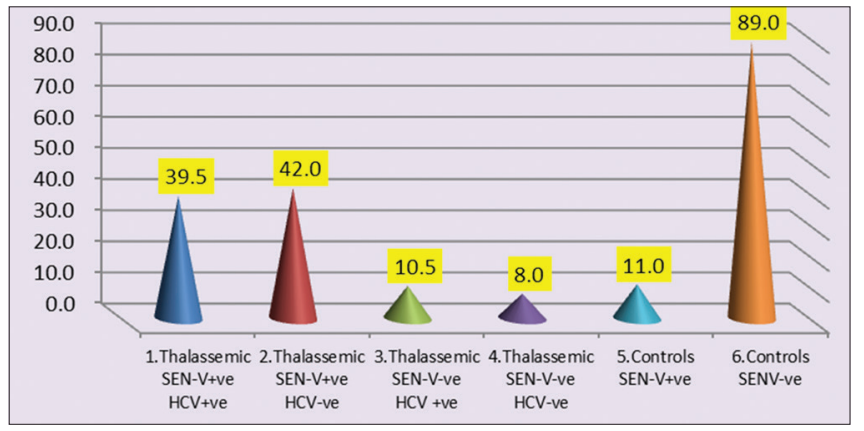

Figure 1: Prevalence of thalassemia and healthy subject's subgroups 
Table 1: Amplification results of HCV-genome by RT-PCR in patients with positive anti-HCV antibodies

\begin{tabular}{|c|c|c|c|c|c|}
\hline \multirow[t]{2}{*}{ Subjects } & \multicolumn{3}{|c|}{ RT-PCR } & \multirow[t]{2}{*}{ Total } & \multirow[t]{2}{*}{$P$ value } \\
\hline & $\mathrm{ND}^{*}$ & Positive & Negative & & \\
\hline \multicolumn{6}{|l|}{ Patients } \\
\hline \multicolumn{6}{|l|}{ ELISA } \\
\hline Positive & 28 & 72 & 0 & 100 & $0.000^{*}$ \\
\hline Negative & 0 & 0 & 100 & 100 & \\
\hline Total (\%) & $28(100.0)$ & $72(100.0)$ & $100(100.0)$ & $200(100.0)$ & \\
\hline \multicolumn{6}{|l|}{ Healthy } \\
\hline \multicolumn{6}{|l|}{ ELISA } \\
\hline Negative & 0.00 & 0.00 & 100 & 100 & \\
\hline Total (\%) & 0.00 & 0.00 & $100(100.0)$ & $100(100.0)$ & \\
\hline
\end{tabular}

*Significant difference between proportions using Pearson Chi-square test at 0.05 levels

Table 2: The occurrence of SENV DNA among thalassemia patients and healthy subjects

\begin{tabular}{lccc} 
SEN virus PCR & Thalassemia (\%) & Healthy subjects (\%) & Total (\%) \\
\hline Positive $n(\%)$ & $163(81.5)$ & $11(11.0)$ & $174(58.0)$ \\
Negative $n(\%)$ & $37(18.5)$ & $89(89.0)$ & $126(42.0)$ \\
Total & 200 & 100 & 300 \\
& 100.0 & 100.0 & 100.0 \\
\hline
\end{tabular}

*Significant difference between proportions using Pearson Chi-square test at 0.05 levels. PCR: Polymerase chain reaction

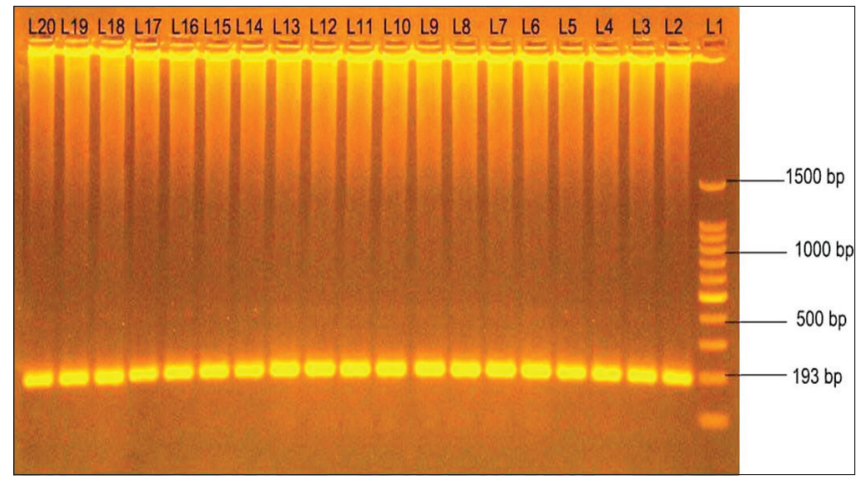

Figure 2: Agarose gel electrophoresis (2\%) with Redsafe stain for amplified SEN-DNA. Bands with amplified SEN-V gene revealed a SENV-D band with 193 bp as reflected in $L 2$, L3, L4, L5, L6, L7, L8, L9, L10, L11, L12, L13, L14, and L15, in addition to L16. DNA ladder with (100-1500 bp) on the right (L1) was used as a DNA molecular weight marker

Our study results revealed that the comparison of SENV genotypes among thalassemia patients with or without HCV coinfection and healthy subjects was achieved. Thalassemia patients who were not infected with HCV (84\%) were significantly increased than those observed in healthy subjects (11\%). Furthermore, thalassemia patients coinfected with SENV and HCV (79\%) were significantly increased than in healthy subjects $(11 \%)(P<0.05)$.

The results revealed that there was a substantial increase in SENV-D in thalassemia patients without HCV infection (59\%) than those in thalassemia patients with HCV infection (44\%) and healthy subjects $(7 \%)(P<0.05)$ [Figure 4$]$.
In the present study, there was significant difference $(P \leq 0.005)$ inactivity of ALT, AST, and ALP enzyme in sera of HCV patients coinfected with SEN-V $(60.589 \pm 21.81$, $57.08 \pm 35.9$, and $138.2 \pm 43.3$ ), respectively, and in SEN-V patients $(56.69 \pm 19.42,54.58 \pm 13.1$, and $120.3 \pm 70.2)$, respectively, as compare with healthy subjects $(25.59 \pm 8.0$, $20.1 \pm 6.94$, and $74.11 \pm 27.7$ ), respectively. Furthermore, there was significant difference $P \leq 0.005$ in the activity of GGT and TSB in sera of HCV patients coinfected with SEN-V $(54.06 \pm 64.9$ and $2.94 \pm 1.49)$ and SEN-V patients (49.33 \pm 40.9 and $2.25 \pm 1.16)$ as compared with healthy subjects (25.21 \pm 9.1 and $0.74 \pm 0.32)$, respectively [Table 3 ].

\section{Molecular Study and Phylogenetic Analysis of SENV}

\section{SENV-D genotype}

A total of 14 samples of amplified SENV DNA had been sent for sequencing that was carried out by NICEM Company (South Korea). The study result revealed that 14 samples were infected with SENV-D genotype only as yielded after sequencing and phylogenetic tree representation[Figure 5]. Two (14.3\%) of them from blood donor (no. 22 and 23) were infected with D genotype only, and nine (64.3\%) from thalassemia patients group (no.1, 5, 6, 8, 17, 18, 19, 20, and 21) were infected with the same genotype only. On the other hand, three (21.4\%) of these patients (no.2, 3, and 4) were coinfected with $\mathrm{D}$ and $\mathrm{H}$ genotypes at the same time. Alignment study of SEN genotypes D in thalassemia patients revealed that there is closely related genotype to the unique ones which isolated 


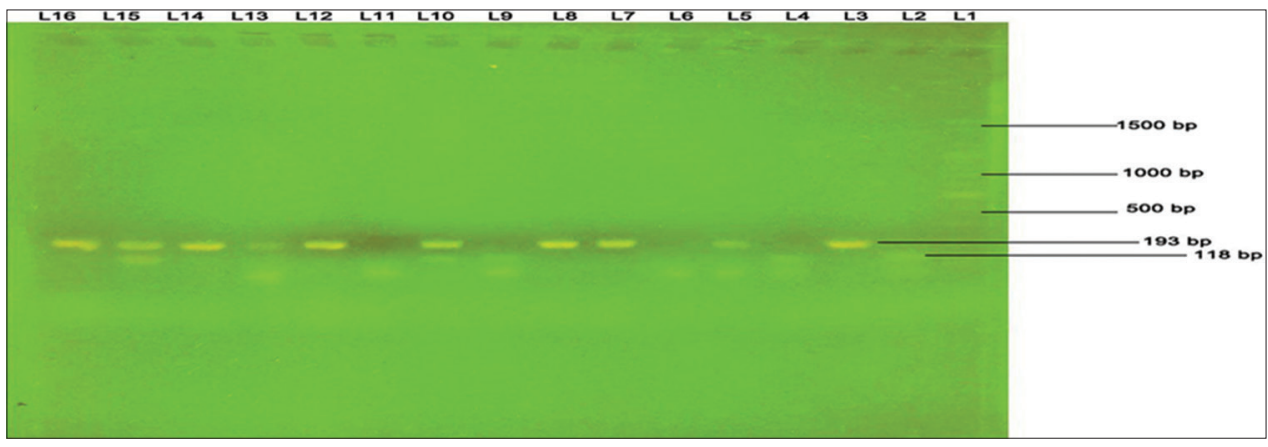

Figure 3: Copresence of both of SENV-D and SENV-H as yielded in lanes L5, L10, and L15 after achievement of agarose gel electrophoresis (2\%) with Redsafe stain. DNA ladder with (100-1500 bp) on the right (L1) was used as DNA weight marker

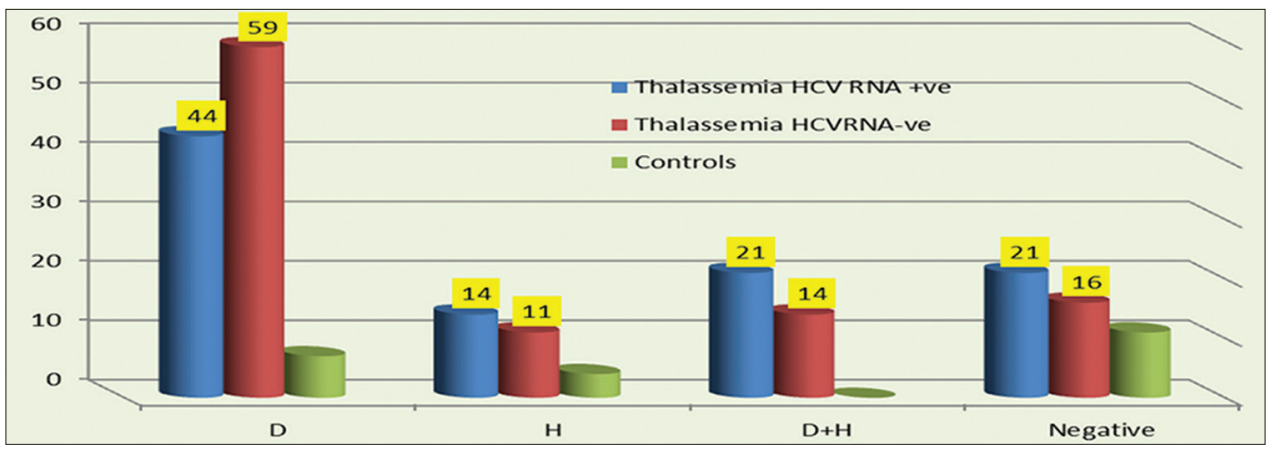

Figure 4: Distribution of SENV genotypes among the thalassemia patients with or without HCV infection and healthy subjects

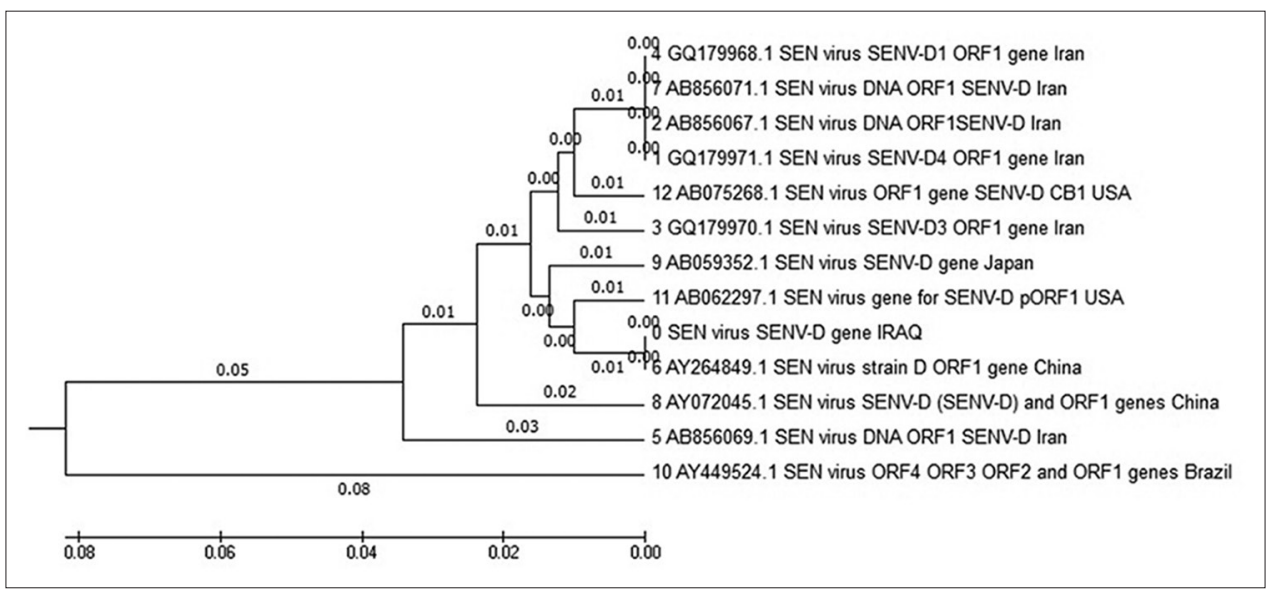

Figure 5: Phylogenetic analysis tree of Iraqi SENV-D genetic distance with other global

from Iran, China, Japan, Brazil, and United States deposit in the Genbank with accession numbers documented in the following Table 4. Further, the sequencing of these genes revealed that the compatibility range was $83-99 \%$ in comparison with the global standard gene in a Gennank in NCBI.

In the sequencing study of a SEN-D gene obtained and amplified from clinical research isolates no 1, 2, 3, 4, 5, 6, 8, $17,18,19,20,21,22$, and 23 were corresponds to the global number ID: GQ179971.1 for all sample. The sequencing results also revealed that after the alignment of product, amplification of SEN-D gene having one types of substitution (Transition) from the Genbank. The sequencing and BLAST analysis of partial SEN-D gene and types of polymorphism for the gene are reflected in Table 5.

\section{DISCUSSION}

Several diseases depend on blood transfusion as a way of disease management; one of these diseases is thalassemia especially $\beta$ type, so regular blood transfusion considered as the only way for maintaining of patient's life. ${ }^{[24]}$ Some of the blood-borne viruses are common and have a determinative role in the outcome of patients with thalassemia. Viral hepatitis infections, including HBS and especially HCV, 


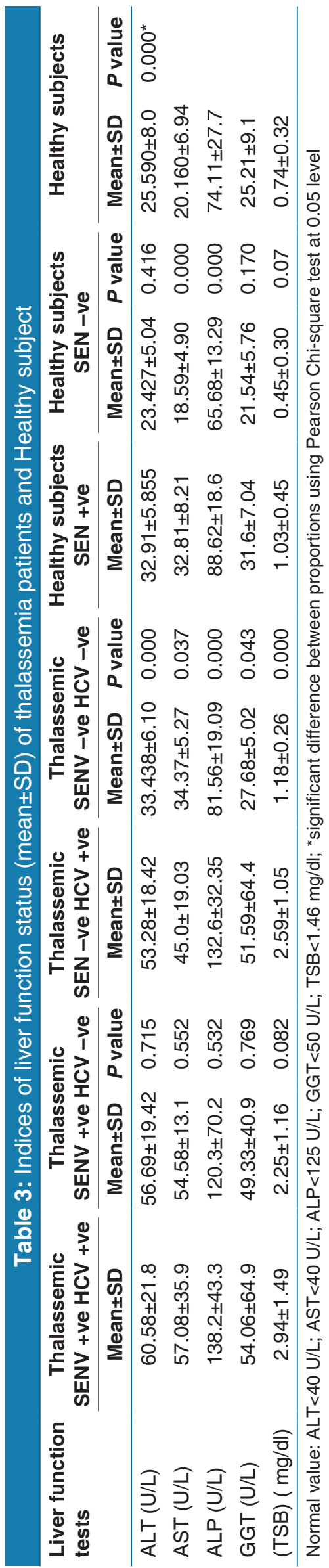

are at a higher risk of interfering in the pathophysiology of thalassemia. ${ }^{[25]}$ SENV has been recently identified as a putative agent for non-A-E hepatitis. However, the exact role of this virus in the pathogenesis of liver diseases, including acute and chronic hepatitis, cirrhosis, and the development of HCC remains to be verified. ${ }^{[26]}$

In our study, SENV infections had been identified by DNA extraction, DNA amplification by PCR. The statistical investigation of results revealed that in Iraq, the prevalence rate of SENV DNA in thalassemia patients is $163(81.5 \%)$ while in healthy blood donors are $11.0 \%$ which means it was increased sharply in the prevalence. Basheer and associates ${ }^{[27]}$ indicated that SENV is a relatively common viral infection (19.0\%) among healthy individuals who attended the Blood Bank Center for Donation in Nyala Teaching Hospital. SENV was detected in $43.0 \%$ of thalassemic patients and $10.7 \%$ of blood donors by Al-Zubaidi et al. ${ }^{[14]}$ in 2016 from Iraq, and the high prevalence of SENV among thalassemic patients may be due to multiple transfusion.

The prevalence of SENV in Pakistan is comparatively lower both inpatients and healthy subjects groups as compared with previous reports from different geographical regions of the world. ${ }^{[6,28]}$ Other statements from different parts of the globe showed that lower prevalence of SENV when compared with the results of the current study ${ }^{[29]}$ which confirms the variability in the seroprevalence of SENV across the world. In another study laid down by Hosseini and Bouzari, ${ }^{[6]}$ the researchers reported that SENV was detected in $90.0 \%$ of healthy individuals even higher than high-risk group while other reports from the different province of Iran yielded contrary results. ${ }^{[10]}$ The possible reason behind this variability of SENV prevalence in different geographical regions of the world might be the lifestyle, socioeconomic status, standard of health-care facilities, knowledge, skills and training of health-care providers, number of surgical procedures, number of transfusions, duration of hemodialysis, intravenous drug use, unsafe sexual practices, homosexuality, and professional exposure. In a study done by Amir et al. ${ }^{[30]}$, they just focused on considering the presence of SENV in thalassemia patients who receive multiple transfusions and no statistical analysis was applied to find out the association between numbers of transfusions, ages of considered groups, and other possible risk factors.

Concerning SENV occurrence, there was a significant increase in SENV occurrence in thalassemia patients than those observed in healthy subjects $(P>0.05)$ regardless of $\mathrm{HCV}$ infection. Thalassemia patients coinfected with SENV and $\mathrm{HCV}$ were significantly lower than those seen in a group of patients not infected with HCV this may be due to the same risk factor of the HCV such as blood transfusion in this region. SENV infection in HCV patients without a history of transfusion revealed that the routes other than blood transfusion must be involved. Nowadays, intravenous drug abuse is the primary risk factor for $\mathrm{HCV}$ infection. ${ }^{[31]}$ The high 
Table 4: The BLAST results of SENV-D DNA in the Genbank, and compatibility of DNA sequences obtained

from National Center Biotechnology Information (NCBI)

\begin{tabular}{lllc} 
Accession & Country & Source & Compatibility (\%) \\
\hline ID: GQ179971.1 & Iran & SEN virus isolate Guilan SENV-D4 ORF1 gene & 99 \\
ID: AB856067.1 & Iran & SEN virus DNA, ORF1, partial sequence, strain: SENV-D & 99 \\
ID: GQ179970.1 & Iran & SEN virus isolate Guilan SENV-D3 nonfunctional ORF1 gene & 99 \\
ID: GQ179968.1 & Iran & SEN virus isolate Guilan SENV-D1 nonfunctional ORF1 gene & 97 \\
ID: AB856069.1 & Iran & SEN virus DNA, ORF1, partial sequence, strain: SENV-D & 97 \\
ID: AY264849.1 & China & SEN virus strain D isolate BJ-2 ORF1 gene & 96 \\
ID: AB856071.1 & Iran & SEN virus DNA, ORF1, partial sequence, strain: SENV-D & 95 \\
ID: AY072045.1 & China & SEN virus SENV-D (SENV-D) and ORF1 genes & 95 \\
ID: AB059352.1 & Japan & SEN virus SENV-D gene & 91 \\
ID: AY449524.1 & Brazil & SEN virus isolate 5-A ORF4, ORF3, ORF2, and ORF1 genes & 83 \\
ID: AB062297.1 & USA & SEN virus gene for SENV-D pORF1 & 93 \\
ID: AB075268.1 & USA & SEN virus ORF1 gene & 98 \\
\hline
\end{tabular}

Table 5: The characteristics of positive SENV-D genotypes among clinical samples

\begin{tabular}{|c|c|c|c|c|c|}
\hline Number of isolation & Type of substitution & Location & Nucleotide & Sequence ID & Identities (\%) \\
\hline 1 & & & & ID: GQ179971.1 & 100 \\
\hline 2 & Transition & 72 & $\mathrm{C}>\mathrm{T}$ & ID: GQ179971.1 & 99 \\
\hline \multirow[t]{2}{*}{3} & Transition & 49 & $A>G$ & ID: GQ179971.1 & 99 \\
\hline & Transition & 72 & $C>T$ & & \\
\hline 4 & Transition & 72 & $C>T$ & ID: GQ179971.1 & 99 \\
\hline 5 & Transition & 72 & $C>T$ & ID: GQ179971.1 & 99 \\
\hline \multirow[t]{2}{*}{6} & Transition & 49 & $A>G$ & ID: GQ179971.1 & 99 \\
\hline & Transition & 72 & $C>T$ & & \\
\hline \multirow[t]{4}{*}{8} & Transition & 49 & $A>G$ & ID: GQ179971.1 & 97 \\
\hline & Transition & 72 & $C>T$ & & \\
\hline & Transition & 83 & $A>G$ & & \\
\hline & Transition & 104 & $C>T$ & & \\
\hline 17 & Transition & 83 & $A>G$ & ID: GQ179971.1 & 99 \\
\hline 18 & Transition & 83 & $A>G$ & ID: GQ179971.1 & 99 \\
\hline \multirow[t]{3}{*}{19} & Transition & 49 & $A>G$ & ID: GQ179971.1 & 98 \\
\hline & Transition & 72 & $C>T$ & & \\
\hline & Transition & 83 & $A>G$ & & \\
\hline \multirow[t]{3}{*}{20} & Transition & 49 & $A>G$ & ID: GQ179971.1 & 98 \\
\hline & Transition & 72 & $C>T$ & & \\
\hline & Transition & 83 & $A>G$ & & \\
\hline \multirow[t]{3}{*}{21} & Transition & 49 & $A>G$ & ID: GQ179971.1 & 98 \\
\hline & Transition & 72 & $C>T$ & & \\
\hline & Transition & 83 & $A>G$ & & \\
\hline \multirow[t]{4}{*}{22} & Transition & 49 & $A>G$ & ID: GQ179971.1 & 97 \\
\hline & Transition & 72 & $C>T$ & & \\
\hline & Transition & 83 & $A>G$ & & \\
\hline & Transition & 104 & $C>T$ & & \\
\hline \multirow[t]{3}{*}{23} & Transition & 49 & $A>G$ & ID: GQ179971.1 & 98 \\
\hline & Transition & 72 & $C>T$ & & \\
\hline & Transition & 83 & $A>G$ & & \\
\hline
\end{tabular}


prevalence of SENV infection in Iranian healthy blood donors suggested that non-parenteral transmission can occur. ${ }^{[10]}$

The high association of SENV with HCV among chronic hepatitis $\mathrm{C}$ patients suggests that HCV and SENV may share common routes of transmission. SENV might be transmitted by parenteral routes and iatrogenic means in a hospital setting. Furthermore, the high prevalence of the virus suggests the non-parenteral route of transmission. It is supported by the fact that SENV prevalence in patients with acute hepatitis. An infection which is transmitted by fecal-oral route is higher than in healthy adults. Furthermore, vertical transmission from mother to fetus does occur. ${ }^{[32]}$ Blood-borne diseases, especially with the $\mathrm{HCV}$, are a significant problem for thalassemic patients. ${ }^{[33]} \mathrm{SEN}$ virus infection in thalassemic patients infected with $\mathrm{HCV}$ and thalassemic patients might be attributed to the need for blood transfusion in these patients. ${ }^{[34]}$ Transmission routes of SENV infection might be mostly parenteral, for example, transmission by blood transfusion, intravenous drug use, or hemodialysis. ${ }^{[35]}$

The study revealed that the occurrence of SENV-D in thalassemia HCV RNA positive was $44.0 \%$ while the incident was increased in thalassemia HCV RNA contrary to $59.0 \%$ and healthy subjects group $7.0 \%$, SENV-D was higher among HCV RNA negative than those with thalassemia HCV RNA positive patients. SENV was detected in a considerable percentage of chronic hepatitis patients with genotype D being the most prevalent.

In a study designed by Elsherbiny et al. ${ }^{[36]}$, the researchers were detected SENV in $28.6 \%$ of patients with chronic liver disease $(32 / 112)$ and $15 \%(3 / 20)$ of the healthy subjects group. The most common genus identified in both groups was SENV H in $38.5 \%$ and $33.3 \%$, respectively. However, SENV $\mathrm{D}$ was the only genus identified in healthy subjects $(100 \%)$. In contrast to the present study, it has been demonstrated that SENV-H is more prevalent than SENV-D in HCV infected patients in Iran. ${ }^{[5,6]}$ This may be due to in different geographical regions of the world, socioeconomic status, the standard of health-care facilities, number of transfusions, duration of hemodialysis, and intravenous drug use.

Thalassemia group had been subdivided according to the SENV and HCV infections into four subgroups, HCV positive and SENV positive as subgroup I, SENV positive and HCV negative as subgroup II, SENV negative and HCV positive as subgroup III, and SENV and negative and HCV negative as subgroup IV. Healthy subjects also had been subdivided into two subgroups according to SENV infection because they had been chosen as HCV free to be healthy persons, SENV positive (subgroup V) and SENV negative (subgroup VI). From the above results of the present study statistically, substantial, significant differences observed between groups (Thalassemia patients who were harboring $\mathrm{HCV}$ and SEN virus and healthy subject) $(P=0.000)$. Also, it was observed that significant differences between patients group and healthy subjects who are harboring SEN virus considering that this result was considered clinically negligible because the values of ALT remain within the normal value $(<40 \mathrm{U} / \mathrm{L})$. There were significant elevations in the liver enzyme in thalassemia patients with SENV positive HCV positive and SENV positive HCV negative as compared with healthy subject SEN positive and healthy subject SEN negative. SENV can cause increasing on the ALT level, but it produces a considerable increase on ALT level especially in the condition of HCV coinfection. The significant increase has appeared in ALT levels among subgroups above normal range was inconsistent with the study of Abbas and others in Iran; he was noticed that there was no significant difference in the mean of liver enzymes levels between SENV positive and SENV negative in healthy blood donors and thalassemia patients. ${ }^{[37]}$ This finding was also observed in another study ${ }^{[14]}$ that reported that SENV and HCV coinfection significantly increases AST level above the normal range. SENV substantially increases ALT level above the normal range and has a tremendous significant ALT level increase with HCV coinfection.

ALT levels had significantly been affected by HCV infection, and this describes the fact of HCV infection on the liver. The other high results of ALT in thalassemia HCV RNA negative may have resulted from the same cause of iron overload and iron chelating drugs. On the other hand, in the present study, there was a significant increase in the activity of AST enzyme between group (Thalassemia patients who were harboring HCV and SEN virus and healthy subject) $(P=0.000)$. There were significant elevations in the liver enzyme in thalassemia patients with and SENV positive $\mathrm{HCV}$ positive and SENV positive HCV negative as compared with healthy subject SEN positive and healthy subject SEN negative. Nazish et al. ${ }^{[12]}$ noticed that $75 \%$ of the SEN virus-positive patients had severely deranged AST levels ( $>60 \mathrm{IU} / \mathrm{L})$, and $25 \%$ had moderately demented AST levels (40-60 IU/L). 50\% of SEN virus-positive patients have moderately deranged ALT levels (30-45 IU/L). 25 of SEN virus-positive patients has severely demented ALT levels (>45). Rizvi et al. ${ }^{[26]}$ also reported the same finding regarding the biochemical parameters in Indian study that deranged liver function tests were observed in the majority of the patient. $73.52 \%$ had deranged AST levels while $79.41 \%$ patients had demented ALT levels. The present study was also consistent with the findings of other studies that showed that the majority of the HCV-RNA positive subjects had elevated ALT levels in acute hepatitis. A significant proportion of the chronic liver disease patients had normal serum ALT levels, probably reflecting the fluctuations of ALT levels in chronic HCV cases which revealed that substantial liver disease might be present in chronic patients irrespective of viral load, genotype, and ALT levels. ${ }^{[38]}$ In about $60 \%$ liver cancer alpha-fetoprotein levels are elevated ALT along with AST is most commonly used markers for hepatocyte injury; ALT levels often rise to the very high level in a patient with acute viral hepatitis. ${ }^{[38]}$

In the present study, there was an observed increase in the activity of GGT enzyme in sera of coinfection patients as compared with healthy subjects, $P<0.00$. Furthermore, there 
was a considerable increase in the activity of GGT enzyme in sera of SENV patients and HCV patients as compared with healthy subjects. GGT has been widely used as an index of liver dysfunction and marker of high alcohol consumption, obstructive liver diseases, and use of enzyme-inducing drugs, lead to increased free radical production, and the threat of glutathione depletion. It is an enzyme playing an essential role in the catabolism of extracellular GSH which is the representative of intracellular antioxidant. ${ }^{[39]}$ Huang et al. ${ }^{[40]}$ suggested that results from several recent studies, however, have indicated that serum GGT might be of diagnostic value. First, elevated GGT has been shown to be revealed and detected dramatically with the progression of mortality in liver diseases, cancer, and diabetes in the United States. Second, the serum GGT level is elevated in patients with chronic hepatitis C. ${ }^{[41]}$

The phylogenetic tree represented in Figure 5 appeared that these samples in each branch have the same DNA sequences. It means that the virus had been transmitted most probably through blood transfusion as a result of the compatibility of DNA sequences between donors and thalassemia patients and $\mathrm{D}$ sequence of the coinfected persons with SEN-V D and $\mathrm{H}$ is the same sequence of D genotype of the SEN-V-D infected person. SEN-V-D DNA had been aligned, and the results revealed that there was $99 \%$ compatibility with the SEN-V-D DNA study in Iran. Moreover, alignment results showed that $98 \%, 96 \%, 91 \%$, and $83 \%$ were revealed compatibility with the USA, China, Japan, and Brazil, respectively. ${ }^{[42]}$

The study suggested that the occurrence rate of SEN-V DNA in thalassemia patients is very high in comparison with those observed in healthy blood donors. Such frequency of SENV infection among thalassemic patients suggests that blood transfusion is a primary route of transmission. Furthermore, In Iraq, significant coinfection is concluded in thalassemic patients either by SEN-V-D or with SEN-V-H or both of them. Further, in the genotypic study, SEN-V-D genotype is more prevalence and frequent in Iraqi thalassemic patients and healthy subjects groups. The sequences of SENV D genotype revealed, compatibility range (83-99\%), with the global standard gene in Genbank documented in NCBI. The most countries have similar sequences to Iraqi SENV-D genotype sequence are Iran, China, Japan, Brazil, and the United States of America.

\section{ACKNOWLEDGMENT}

The author represents deep gratitude to Dr. Satar A. Hamood, specialty GIT-Al-Karamah Teaching Hospital, Thalassemia Center, Baghdad, for his assistance in providing the researchers with a clinical sample of this study.

\section{REFERENCES}

1. Harfouche M, Chemaitelly H, Mahmud S, Chaabna K, Kouyoumjian SP, Al Kanaani Z, et al. Epidemiology of hepatitis $\mathrm{C}$ virus among hemodialysis patients in the middle east and North Africa: Systematic syntheses, meta-analyses, and meta-regressions. Epidemiol Infect 2017;145:3243-63.

2. Engle RE, Bukh J, Alter HJ, Emerson SU, Trenbeath JL, Nguyen HT, et al. Transfusion-associated hepatitis before the screening of blood for hepatitis risk factors. Transfusion 2014;54:2833-41.

3. Vasmehjani A, Yaghoubi S, Hashemi S, Farahmand M, Adeli O, Taravand A, et al. The prevalence of hepatitis B hepatitis $\mathrm{C}$ and human immunodeficiency virus infections among $\beta$-thalassemia major: A multicenter survey in Lorestan, West of Iran. Iran J Pediatr Hematol Oncol 2018;8:1111-7.

4. AL-Jabali I. Torque teno virus (TTV) infection and genotype in Iraqi thalassemia patients. Int J Sci Technol 2014;9:373-432.

5. Din G, Malik S, Ali I, Ahmed S, Dasti JI. Prevalence of hepatitis $\mathrm{C}$ virus infection among thalassemia patients: A perspective from a multiethnic population of Pakistan. Asian Pac J Trop Med 2014;7:127-33.

6. Hosseini SA, Bouzari M. Detection of SENV virus in healthy, hepatitis B and hepatitis C-infected individuals in Yazd Province, Iran. Iran Biomed J 2016;20:168-74.

7. Sagir A, Kirschberg O, Heintges $T$, Erhardt A, Häussinger D. SEN virus infection. Rev Med Virol 2004; 14:141-8.

8. Pirouzi A, Bahmani M, Feizabadi MM, Afkari R. Molecular characterization of torque teno virus and SEN virus co-infection with HIV in patients from Southern Iran. Rev Soc Bras Med Trop 2014;47:275-9.

9. Karimi-Rastehkenari A, Bouzari M. High frequency of SEN virus infection in thalassemic patients and healthy blood donors in Iran. Virol J 2010;7:1.

10. Dehkordi P, Doosti A. The prevalence of SEN virus infection in blood donors and chronic hepatitis $\mathrm{B}$ and $\mathrm{C}$ patients in Chaharmahal VA Bakhtiari province. J Cell Anim Biol 2011;5:182-6.

11. Chhatwal J, Wang X, Ayer T, Kabiri M, Chung RT, Hur C, et al. Hepatitis $\mathrm{C}$ disease burden in the United States in the era of oral direct-acting antivirals. Hepatology 2016;64:1442-50.

12. Nazish M, Rizvi M, Azam M, Haque S, Malik A. A study of prevalence and associated risk factors of SEN virus in haemodialysis patients. Int $\mathrm{J}$ Curr Microbiol 2015;1:134-42.

13. Yoshida EM, Buczkowski AK, Giulivi A, Zou S, Forrester LA. A cross-sectional study of SEN virus in liver transplant recipients. Liver Transpl 2001;7:521-5.

14. Al-Zubaidi B. A Genotypic Study of SEN Virus in Healthy Blood Donors and Thalassemia Patients; with or without HCV Infection and its Clinical Importance. Iraq: Thesis Submitted to the College of the Medicine/ University of Al-Mustansiriyah; 2015.

15. Afkari R, Galati H, Ababa N, Their A, Sekhavati E, Mola F. The prevalence of TTV and SENV among children who born to HIV-infected mothers. Health Sci 
2016;5:158-63.

16. Majeed YH, Al-Ouqaili MT, Jasim MA. Sero-prevalence of hepatitis $\mathrm{C}$ virus antibody among screened populations and certain risk groups in Al-Anbar governorate. West of Iraq. Al-Anbar Med J 2017;14:33-9.

17. Green MR, Sambrook J. Molecular Cloning: A Laboratory Manual. Vol. 3. Cold Spring Harbor, New York: Set Cold Spring Harbor Laboratory Press; 2012.

18. Al-Ouqaili MT, Al-Hayani NN, Saadoon IH. Detection of rhinovirus and some DNA/RNA viruses by reverse transcriptase real-time PCR and their immunological parameters in patients with acute respiratory tract infection in Iraq. Int J Pharm Sci Res 2019;10:1000-11.

19. Al-Ouqaili MTS, Al-Kubaisi SH. Molecular genetics study on high and intermediate risk genotypes of human papilloma virus among patients with benign and malignant cervical lesions. Int $\mathrm{J}$ Pharm Sci Res 2019;10:1000-9.

20. Kang Q, Parkin B, Giraldez MD, Tewari M. Mutant DNA quantification by digital PCR can be confounded by heating during DNA fragmentation. Biotechniques 2016;60:175-6, 178, 180 passim.

21. Amin I, Jabbar T, Niazi F, Akhtar MS. Extraction of HCV-RNA from plasma samples: Development towards semi automation. Int J Anal Chem 2015;2015:367801.

22. Tamura K, Stecher G, Peterson D, Filipski A, Kumar S. MEGA6: Molecular evolutionary genetics analysis version 6.0. Mol Biol Evol 2013;30:2725-9.

23. Simon SD. Statistical Evidence in Medical Trails. What Does the Data Tell Us? New York: Oxford University Press; 2006.

24. Al-Ouqaili MT, Al-Taei SA, Al-Najjar A. Molecular detection of medically essential carbapenemases genes expressed by Metallo- $\beta$-lactamase producer isolates of Pseudomonas aeruginosa and Klebsiella pneumoniae. Asian J Pharm 2018;12 Suppl 3:S991-1001.

25. Loizou C, Phellas C, Beck S, Karekla M, Talias M, Christou S, et al. How life would be without thalassaemia: Patients' perceptions. Cyprus Rev 2016;28:33.

26. Bastani MN, Bokharaei-Salim F, Keyvani H, Esghaei M, Monavari SH, Ebrahimi M, et al. Prevalence of occult hepatitis $\mathrm{C}$ virus infection in Iranian patients with beta thalassemia major. Arch Virol 2016;161:1899-906.

27. Rizvi M, Jahan S, Azam M, Ajmal MR, Shukla I, Malik A, et al. Prevalence and assessment of role of SEN virus in acute and chronic hepatitis in India. Trop Gastroenterol 2013;34:227-34.

28. Basheer SH, Elzaki SG, Abaker NM, Abd Elkareem HR, Ali MA. Prevalence of SEN virus infection among volunteer blood donors in Nyala teaching hospital, Southern Darfur state, Sudan. Sch J App Med Sci 2017;5:4441-5.

29. Schréter I, Kristian P, Jarcuska P, Porubcin S, Siegfried L, Birosová E, et al. Detection of SEN virus in the general population and different risk groups in Slovakia. Folia
Microbiol (Praha) 2006;51:223-8.

30. Serin MS, Koksal F, Oksuz M, Abayli B, Aslan G, Tezcan $\mathrm{S}$, et al. SEN virus prevalence among non-B and non-C hepatitis patients with high liver function tests in the south of Turkey. Jpn J Infect Dis 2005;58:349-52.

31. Amir S, Khan J, Afzal MS, Amen NE, Raza H, Safdar W, et al. Molecular epidemiology and genotyping of SEN virus in thalassemia patients in Pakistan. Infect Genet Evol 2016;44:300-2.

32. Al Badry BJ. Epidemiology, mode of transmission and risk factors of hepatitis $\mathrm{C}$ virus (HCV) infections in DhiQar Province/Iraq. Int J 2015;3:1025-32.

33. Kholeif L, Faye D. SEN virus detection in Egyptian patients with chronic hepatitis $\mathrm{C}$ and hepatitis $\mathrm{C}$ related hepatocellular carcinoma. Egypt J Med Microbiol 2008;17:91-7.

34. Mohammadi S, Khodabandehloo M. Prevalence of hepatitis $\mathrm{C}$ virus antibodies among beta-thalassemia major patients in Kurdistan Province, Iran. Arch Clin Infect Dis 2017;12:1-5.

35. Kouyoumjian SP, Chemaitelly H, Abu-Raddad LJ. Characterizing hepatitis $\mathrm{C}$ virus epidemiology in Egypt: Systematic reviews, meta-analyses, and metaregressions. Sci Rep 2018;8:1661.

36. Abbasi S, Makvandi M, Karimi G, Neisi N. The prevalence of SEN virus and occult hepatitis B (OBI) virus infection among blood donors in Ahvaz city. Jundishapur J Microbiol 2016;9:e37329.

37. Elsherbiny N, Hassan A, Ahmed A, El-Rehim A, El Rahim N, Hassany S. Does SEN virus (SENV) infection affect the progression of chronic hepatitis $\mathrm{C}$ or B among Egyptian patients? Afr J Microbiol Res 2015;23:1504-12.

38. Al-Obaid M. Molecular and Serological Study of Hepatitis C Virus from Infected Patients in Al-Anbar Governorate. A Thesis Submitted to the College of Medicine and the Committee of Postgraduate StudiesUniversity of Anbar; 2015.

39. Chethana C, Valliyammal V. Correlation study between serum AFP and ALT (SGPT) levels in acute viral hepatitis. Acta Biomed Sci 2017;4:11-3.

40. Park WY, Koh ES, Kim SH, Kim YO, Jin DC, Song HC, et al. Serum gamma-glutamyltransferase levels predict clinical outcomes in hemodialysis patients. PLoS One 2015;10:e0138159.

41. Huang R, Yang CC, Liu Y, Xia J, Su R, Xiong YL, et al. Association of serum gamma-glutamyl transferase with treatment outcome in chronic hepatitis B patients. World J Gastroenterol 2015;21:9957-65.

42. Güzelbulut F, Sezikli M, Cetinkaya ZA, Ozkara S, Gönen $\mathrm{C}$, Ovünç AO, et al. A lower serum gammaglutamyltransferase level does not predict a sustained virological response in patients with chronic hepatitis $\mathrm{C}$ genotype 1. Gut Liver 2013;7:74-81.

Source of Support: Nil. Conflict of Interest: None declared. 